\title{
Ductility Of fly ash - slag based reinforced geopolymer concrete elements cured at room temperature.
}

\author{
Mahantesh N.B. ${ }^{1^{*}}$, Amarnath. K. ${ }^{2}$, and Raghuprasad B. K. ${ }^{3}$ \\ ${ }^{1}$ Alliance University, Bangalore, India \\ ${ }^{2,3}$ The Oxford College of Engineering, Bangalore, India
}

\begin{abstract}
Ductility of the flexural element is the main governing property for healthy performance of structural element. Although numerous factors contribute towards the ductility of Reinforced Geopolymer Concrete (RGPC) elements, low calcium based fly ash and GGBS have chemical proportions which make RGPC develop significant ductility along with steel reinforcement - when mixed in an intelligent way satisfying structural and economic conditions. In the present research work influence of low calcium fly ash, GGBS, River sand, M-sand, Steel Grade, manufactured fibres and natural fibres are used to study the ductile behaviour of RGPC sections by load testing 51 under reinforced flexural elements. The study reveals that fly ash - slag based reinforced flexural elements behave in line with OPC based RCC elements. The provisions mentioned in Indian RC designer IS:456-2000 can be used to predict the flexural behaviour of reinforced geopolymer concrete elements. The average flexural ductility of these test specimens observed to lie in between $2 \& 3$.
\end{abstract}

Keywords: Ductility, Geopolymer concrete, fly ash, slag, large deflections, flexural behaviour, River sand, Manufactured Sand.

\section{1) INTRODUCTION}

Geopolymer Concrete an environmentally friendly concrete having good structural skills is known structural concrete for the last 50 years, but still ordinary Portland Cement Concrete holds the first place in all construction activities. The manufacturing process of geopolymer concrete needs urgent attention to develop a process which suits the requirement of a most consumed private sector of concrete industry like fast moving consumer product (FMCG). Low calcium based fly ash geopolymer concrete essentially need heat or steam curing which make them unsuitable for cast in situ applications. The cost of curing is the additional factor which has made geopolymer concrete unpopular in most of the construction activities, especially in reinforced concrete structural elements.

*corresponding author: mahanteshb@rediffmail.com 
Ambient curing is the most effective remedy to solve this issue. Industrial waste like slag (ground granulated blast furnace slag), when mixed with fly ash, develops strength at ambient temperature without heat or steam curing keeping the final strength same. During the past 10 - 15 years partial replacement of cement by fly ash \& GGBS is becoming popular because of economic reasons in these sectors of concrete industry, giving ample evidence and data for a complete replacement.

\section{2) MATERIALS USED AND PROPERTIES.}

Fly ash used in this work was collected from Raichur thermal power plant in Karnataka, having sp.gr 2.15, Silicon dioxide $\left(\mathrm{SiO}_{2}\right) 61.98 \%$, Aluminium oxide $\left(\mathrm{Al}_{2} \mathrm{O}_{3}\right) 26.06 \%$, calcium oxide(Cao) $3.05 \%$ confirming to grade 1 of IS 3812. Slag - ground granulated blast furnace slag, was procured from Jindal Steel Plant Bellary-Karnataka, having sp.gr 2.62, Silicon dioxide $\left(\mathrm{SiO}_{2}\right) 33.88 \%$, Aluminum oxide $\left(\mathrm{Al}_{2} \mathrm{O}_{3}\right) 18.02 \%$, calcium oxide $(\mathrm{Cao})$ $34.98 \%$ confirming to IS 12089 .

Manufactured-Sand (M-sand), crushed from granite stone, having Sp.gr 2.45, Fineness Modulus (F.M) 2.70 and River Sand of sandstone origin having F.M 2.62 confirming to Zone III of IS 383-1970 are used as fine aggregates and tested as per IS 2386. Coarse aggregates of granite origin of sizes $20 \mathrm{~mm}, 12.5 \mathrm{~mm} \& 4.75 \mathrm{~mm}$ tested as Per IS2386. These coarse aggregates have water absorption capacity $0.5 \%$ by weight at room temperature 16 to 28 degrees Celsius.

Sodium hydroxide of $97 \%$ purity and sodium silicates with $\mathrm{Na}_{2} \mathrm{O}=14.7 \%$, $\mathrm{SiO}_{2}=29.41 \%$, water $=59.9 \%$ by mass are used as Alkaline Activator Solution using ratio of $\mathrm{Na}_{2} \mathrm{Sio}_{3} / \mathrm{NaOH}=2.5$. Sulphonated naphthalene based superplasticiser, i.e. Conplast SP430 DIS distributed by FOSROC chemicals Bangalore used. Reinforcement is of Fe415 and $\mathrm{Fe} 500$ grades.

Four types of fibres used. They are (1) waste fibres produced from workshop lathe machine labelled as $\boldsymbol{L M F}$ (Lathe machine waste fibre) (2) factory made hook ended steel fibres marked as $\boldsymbol{S F} \mathbf{2}$ of aspect ratio 71 from Bekeart Pvt. Ltd, (3) plane steel fibres without hook end labelled as $\boldsymbol{S F 1}$ from Nevatia Steel \& Alloys Pvt Ltd (4) Polyester fibres marked as $\boldsymbol{P F}$ from Recron 3s Pvt Ltd placed sourced from South Indian Private Companies.

Table 1: Constituents for $1 \mathrm{~m}^{3}$ of Geopolymer Concrete

\begin{tabular}{|c|l|c|l|}
\hline S.No. & Materials & Weight $(\mathbf{k g})$ & Specifications \\
\hline 1 & Fly ash & 276 & $70 \%$ of total fly ash \\
\hline 2 & GGBS $(30 \%)$ & 120 & $30 \%$ of total fly ash \\
\hline 3 & $20 \mathrm{~mm}$ to $12 \mathrm{~mm}$ size CA & 451 & $35 \%$ of total CA \\
\hline 4 & $12 \mathrm{mmto} 4.75 \mathrm{~mm}$ CA & 451 & $35 \%$ of total CA \\
\hline 5 & $4.75 \mathrm{~mm}$ \& down sizes & 389 & $30 \%$ of total CA \\
\hline 6 & River sand & 111 & $20 \%$ of total FA \\
\hline 7 & M-sand & 444 & $80 \%$ of total FA \\
\hline 8 & Sodium hydroxide of $8 \mathrm{M}$ & 45 & $97 \%$ purity \\
\hline 9 & Sodium Silicate(Na $\left.2 \mathrm{sio}_{3}\right)$ & 113 & $\mathrm{Na}_{2} \mathrm{O} 14.7 \%, \mathrm{SiO}_{2} 29.4 \%$ \\
\hline 10 & Super plasticizer & 3.6 & SP430DIS $(1.5 \%)$ \\
\hline \multicolumn{3}{|l}{} \\
\hline
\end{tabular}


Table 1 shows the mix proportions used for all reinforced geopolymer concrete specimens listed in Table 2.

\section{3) SPECIMEN PREPARATION}

Alkaline Activator Solution (AAS) is prepared 24 hours before mixing of concrete. Molarity of the $\mathrm{NaOH}$ solution (SHS) determined by the relation $\mathrm{M}=0.25 \mathrm{PD}$. $\mathrm{M}$ is the molarity of $\mathrm{NaOH}$ solution, $\mathrm{P}$ is concentration of sodium , $\mathrm{D}$ is the density of SHS for P. Therefore to get 1 liter of SHS of 8, 10 and 12 Molarity $(255+745),(306+694)$ and $(354+646)$ of (Sodium Hydroxide pallets in gms + water in gms) added respectively [4]. Cover blocks of $10 \mathrm{~mm}$ thick are used for all specimen to provide clear uniform cover to reinforcements. Compaction of geopolymer concrete while filling in formwork containing reinforcement is done by using vibrators. The side from work removed after 24 hours of casting and specimen are left to room temperature curing which varied from 16 degrees Celsius at night $\& 28$ degrees Celsius during peak daytime.

\section{4) SPECIMEN DETAILS}

To know the ductile capacity of reinforced flexural elements, different parameters which affect the ductility of components taken into considerations and a careful grouping of different specimens to be tested are listed. In all 41 slabs were tested having four different sizes $1.3 m \times 0.65 m, 1 m \times 1 m, 0.8 m \times 0.8 m, 0.975 m \times 0.65 m$ with aspect ratios $1,1.5$ and 2.0. Two types of loads were applied, i.e. CPL Central Point Load and UDL - Uniformly Distributed Load using monotonically increasing load in 50Mton Loading frame.

Table 2: Specimen Groups

\begin{tabular}{|c|c|c|c|c|}
\hline $\begin{array}{c}\text { Group Name } \\
\text { Fine Agg. - Molarity }\end{array}$ & $\begin{array}{c}\text { No \& } \\
\text { Element }\end{array}$ & $\begin{array}{l}\text { Size mm } \\
\text { L x B x D }\end{array}$ & Ast- $\mathrm{NX}-\mathrm{N}_{\mathrm{L}}$ & $\begin{array}{c}\text { fy- fck- } \\
\& \text { curing days }\end{array}$ \\
\hline A1:MS-8M & 8-Slabs & $1300 \times 650 \times 75$ & $8 \mathrm{~mm}-4 \# \& 7 \#$ & Fe500-57.87-36 \\
\hline A2:MS-10M & 8-Slabs & $975 \times 650 \times 75$ & $8 \mathrm{~mm}-4 \# \& 6 \#$ & Fe500-45.96-26 \\
\hline A3: MS-12M & 8-Slabs & $800 \times 800 \times 75$ & $8 \mathrm{~mm}-5 \# \& 5 \#$ & Fe500-41.70-22 \\
\hline B1, B2, B3: MS-8M & 12-Slabs & $1000 \times 1000 \times 60$ & $8 \mathrm{~mm}-7 \# \& 7 \#$ & Fe415-44.20-14 \\
\hline C1: RS-8M & 05-Slabs & $1000 \times 1000 \times 60$ & $8 \mathrm{~mm}-11 \# \& 11 \#$ & Fe415-35-14 \\
\hline $\begin{array}{r}\text { D: BM1 to BM10 } \\
\text { RS-8M }\end{array}$ & 10-Beams & $\begin{array}{l}\text { Top :02\#-8mm } \\
\text { Bot: } 03 \#-12 \mathrm{~mm} \\
\text { 2L-8mm-100c/c }\end{array}$ & $\begin{array}{l}B=150 \mathrm{~mm} \\
D=210 \mathrm{~mm}\end{array}$ & $\mathrm{Fe} 415-35-14$ \\
\hline \multicolumn{5}{|c|}{$\begin{array}{l}\text { Notation: MS- Manufactured sand , RS- River sand : Nx \& } \mathrm{N}_{\mathrm{L}} \text { rebars parallel to Shorter \& } \\
\text { Longer Sides,Fe500- yield stress 533Mpa \& Ultimate stress } 587 \mathrm{Mpa}, \mathrm{Fe} 415-\text { yield stress } 423 \\
\text { Mpa and Ultimate stress 502Mpa,SS- Short sides simply supported \& remaining sides free, fck - }- \\
\text { cube compressive strength Mpa, PF - polyester fibers.PL-plain GPC }\end{array}$} \\
\hline
\end{tabular}

\section{5) LOAD TESTING OF SPECIMENS}

Testing of slabs is done by applying crucial point loads and uniformly distributed loads by using 50MTon self-straining loading frame with electrically operated hydraulic jack. The 
two-point load system at a L/3 distance from both support ends of the beams applied for all the beams. Then the deflections are measured under load points and at the centre of the beam. On the day of testing flexural members - cubes and cylinders were tested.

\section{6) NUMERICAL COMPUTATIONS}

Among the most widely used and easily available aggregates, Granite holds the first place having Young's Modulus varying from $10-70 \mathrm{GPa}$ - far above the values of sandstone rocks, i.e. 1- $20 \mathrm{GPa}$. When Manufactured sand of granite origin as fine aggregate mixed with coarse aggregates of granite origin, with fly ash: slag at 70:30 the resulting composite of granite based geopolymer concrete develops better structural properties. The IS:4562000 describes the relations between compressive strength and flexural strength, modulus of elasticity as $f_{c r}=0.7 \sqrt{f c k}_{\text {ck }}[2]$ and $E_{c}=5000 \sqrt{ }$ fck after 28 days of curing [9]. These expressions are very closely following for fly ash: GGBS ratio at 70:30. [3]

All slabs and beams are analysed using conventional elastic theory for the applied loads and provided boundary condition using geometrical \& material properties like compressive strength, steel strength as listed in Table 1. The failure mechanism of reinforced geopolymer concrete flexural elements follows the conventional OPC based RCC behaviour. The numerical computations are done using IS 456-2000.Until the appearance of the first crack at centre bottom of slab and beam, the composite is linearly elastic. Assessing the strength at this stage, using a full section of concrete results into more moment of inertia gives fewer deflections than measured ones. The composite continues to behave linearly elastic till tensile steel yields. Deflection calculations based on the effective moment of inertia using local code give noticeably matching with actual deflections.

Using $0.67 \mathrm{fck}$ as peak stress in compression concrete with parabolic stress blocks gives maximum strain 0.0020 to 0.0025 , whereas using $0.85 \mathrm{fck}$ with rectangular stress block gives strains around 0.003 to 0.0035 . Failure loads from both peak stresses are acceptably same. The tensile stress of concrete at all stages are neglected. Calculated flexural cracks widths and measured ones are closely matching and are within acceptable limits at service loads. Beyond this stage, the specimen is said to have failed structurally. Further loading on the specimen is treated as post failure stage where significant deflections are observed.

\section{7) FLEXURAL DUCTILITY OF GEOPOLYMER CONCRETE}

If the constituent materials of concrete are ductile, then the concrete can be made more ductile by adding tension steel to develop the desired ductility so that the structures respond elastically at low cost. The plain geopolymer concrete under increasing flexure stress develops compression strains from 0.0010 to 0.0045 [5]. While reinforcement steel (Fe415) 0.0045 to 0.015 (yielding to failure). This reflects on strain ductility of 4.5 for GPC and steel 3.33. These values indicate the possible ductility of resulting composite, i.e. RGPC when subjected to pure flexural stresses.

For the known geometrical \& material properties - analytically yield load $\mathbf{F}_{\mathbf{y}}$ \& ultimate load $\mathbf{F}_{\mathbf{u}}$ is determined. Corresponding deflections $\Delta_{\mathrm{y}} \& \Delta_{\mathrm{u}}$ are read from load Vs deflection curves are drawn by using laboratory measurements. Then Ductility (calculated) $=\Delta \mathbf{u} / \Delta_{\mathbf{y}}$, and Ductile Load D. L = F $/ F_{y}$. Similarly, Strain Hardening Slope for calculated one $=$ SHS cal $=$ Ductile Load $($ calculated $) /$ Ductility $($ cal)

Similarly, Ductility (measured $)=\Delta \mathbf{u m} / \Delta \mathbf{y}, \Delta \mathbf{u m}$ is the maximum deflection the component undergone under maximum applied load $\mathbf{F}_{\mathbf{u m}}$ and $\Delta \mathbf{y}$ is the measured deflection at yielding 
of steel. Then Ductile Load D.L $m=F_{u m} / F_{y}$. Similarly, Strain Hardening Slope for measured one $=$ SHS mea $=$ Ductile Load (measured)/Ductility (mea)

Ductility (calculated) \& Ductility (measured) represent the minimum and maximum ductility developed by GPC. The Average Displacement Ductility is the average ductility between these two values, having more probability develops under Normal Quality Control.

\section{8) RESULTS AND DISCUSSION}

The mix design used is based on $77 \%$ of total aggregates to produce $40 \mathrm{Mpa}$ after ambient curing at 16 to 28 degrees Celsius for seven days which includes 24 hours of the rest period. Although M-sand and R-sand have nearly same fineness modulus, using Manufactured sand, the mix provided more than $40 \mathrm{Mpa}$, while using River-sand produced less than $40 \mathrm{Mpa}$ compressive strength. The main reason for the difference in strength may be due to the difference in rock origins of fine aggregates \& coarse aggregate, i.e. M- sand being granite origin mixing with coarse granite aggregates produces excellent bonding, whereas River sand being Sandstone origin produced less bonding with coarse granite aggregates. Moreover, the basic compressive strength of granite (100 to $250 \mathrm{Mpa}$ ) is more than sandstone (20 to $170 \mathrm{Mpa}$ ) making granite based concrete stronger.

With steel fibres, the composites develop improved strengths while PF produced a marginal increase in strength. This indicates that all four types of fibres used were able to develop a good bond with GPC mixture of both types of fine aggregate. The increased compressive strengths are attributed to the property of fibres in delaying the failure by increased deflections.

Fig.1 to Fig.3 represent the developed deflections of the first set of slabs Group $\boldsymbol{A}$. Compared to UDL; Central point loads develop steep \& sudden deflections at all the three stages of loading. The first appearance of a crack in tension concrete, yielding of tension steel and development of peak compressive stresses - passed within a short difference of loads because of stress concentration under the load.

Group B slabs: Compared to Fe500 steel, Fe415 steel is more ductile. As seen from Fig 4, Fig $5 \&$ Table 2- it has produced ductility of slabs around 2.81 without fibres. Manufactured steel fibres increased the average ductility to 3.15 , while the lathe machine fibres could develop around 2.79 and did not influence much on ductility. The lathe machine fibres are of random sizes in a loop form and thus could not align themselves along the major bending axis. However, it is expected that increased percentage and reducing the sizes by cutting them down to aspect ratio 30 could produce more ductility which is cost effective also.

In Group C: As seen from Fig. 6 \& table 2 the average ductility of slabs was limited to 1.64. Using steel fibres slight increase in ductility observed while marginal improvement in ductility was observed using polyester fibres.

In Group $\boldsymbol{D}$ all beams are subjected to two-point load system \& beams with steel fibres developed slightly better ductility compared to 4 beams with polyester fibres. As seen from strength tests on cubes and cylinders, river sand of the type used has the less basic compressive strength right from its parent rock, i.e. Sand Stone has less compressive strength than Granite stone. In addition to this - river and does not develop enough bond with fibres and thus develops less ductility compared to M-sand.

As seen from strength tests on cubes and cylinders, river sand of the type used has less basic compressive strength right from its parent rock. That is, Sand Stone has less compressive strength than Granite stone. In addition to this, the river sand does not develop enough bond with fibres and thus develops less ductility compared to M-sand. 
The applied load Vs measured deflections of all specimens listed from Fig. 1 to 7. Table 3 shows the list of observed ductilities of all 51 test specimens. These results indicate that $\mathrm{M}$ sand based RGPC specimens are more ductile than R-Sand based specimens. With steel fibre, these specimens may further enhance the composite ductility.

Table 4 broadly summarises the ductilities interms of two fine aggregates used. Addition of steel fibres at 1 to $1.5 \%$ could increase the ductility of M-Sand and R-Sand based RGPC. The combination M-Sand with Fe415 reinforcement \& steel fibres produce maximum ductility of 2.97. However, R-Sand with Fe415 reinforcement without any fibres produces the lowest ductility of $\mathbf{1 . 9 1}$.

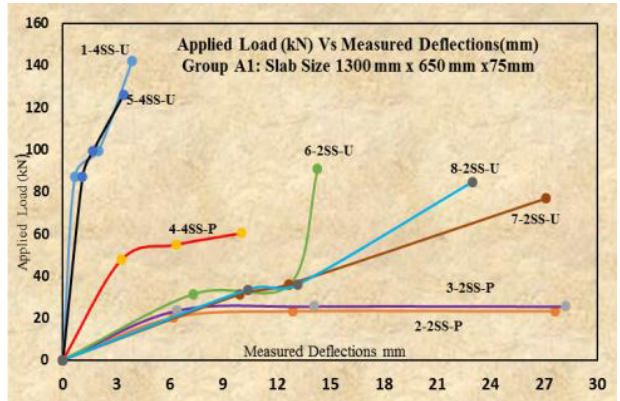

Fig. 1: Applied Load (kN) Vs Measured Deflection $(\mathrm{mm})$ for Group A1- specimens

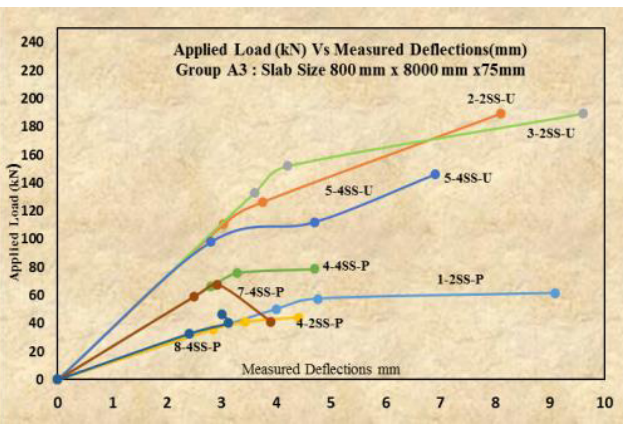

Fig. 3: Load (kN) Vs Measured Deflection (mm) for Group A3- specimens

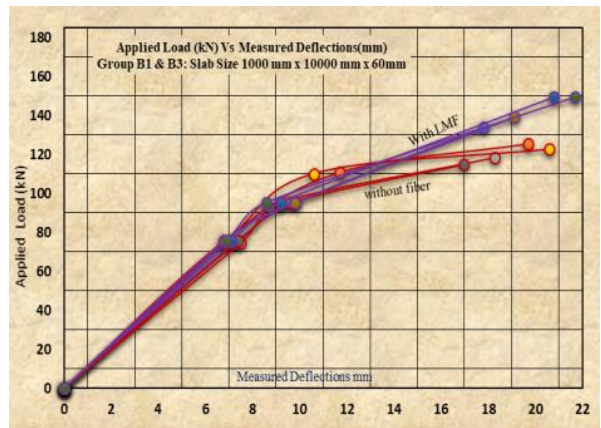

Fig. 5: Load (kN) Vs Measured Deflection (mm) for Group B1-\& B3 specimens

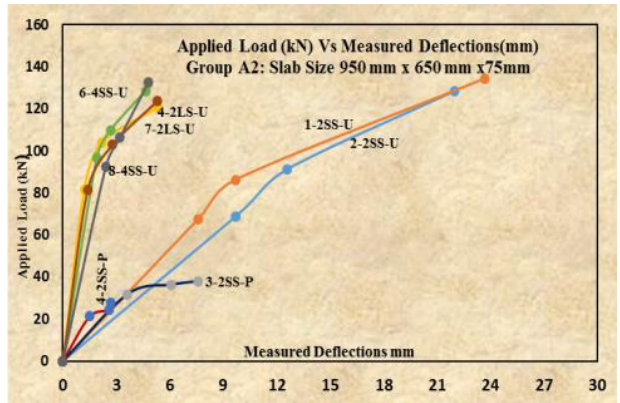

Fig. 2: Load (kN) Vs Measured Deflection (mm) for Group A2- specimens

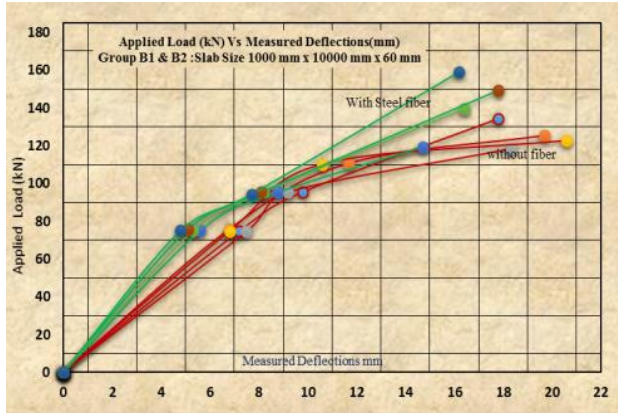

Fig. 4: Load (kN) Vs Measured Deflection (mm) for Group B1 \& B2- specimens

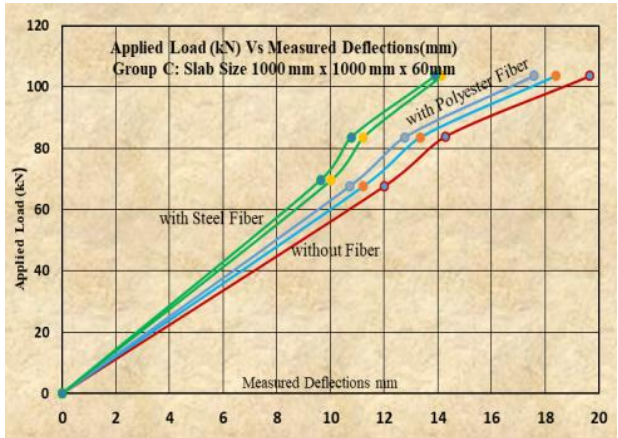

Fig. 6: Load (kN) Vs Measured Deflection (mm) for Group $\mathrm{C}$ specimens 


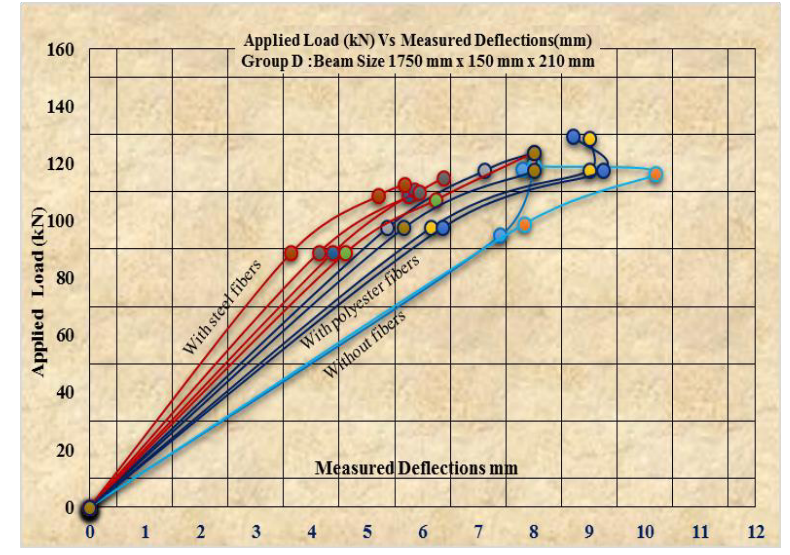

Fig. 7: Load (kN) Vs Measured Deflection (mm) for Group D specimens

Table 3 : Ductility Index of Reinforced Geopolymer Beams \& Slab

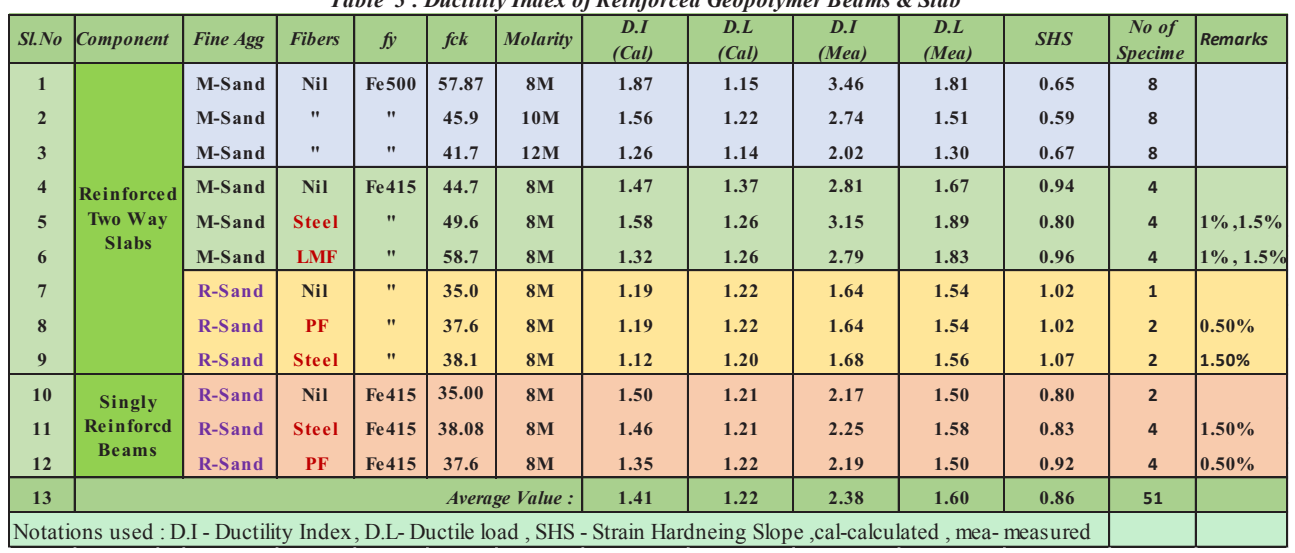

Table 4 : Ductility Ranking of RGPC specimens

\begin{tabular}{|c|c|c|c|c|c|c|c|}
\hline S.No & F. A & Fy & Fiber & $\mathrm{DI}_{\mathrm{cal}}$ & $\mathrm{DI}_{\text {mea }}$ & SHS & D.R \\
\hline 1 & M-sand & $\mathrm{Fe} 415$ & Steel & 1.45 & 2.97 & 0.88 & $\mathbf{I}$ \\
\hline 2 & M-sand & $\mathrm{Fe} 415$ & Nil & 1.47 & 2.81 & 0.94 & II \\
\hline 3 & M-s and & $\mathrm{Fe} 500$ & Nil & 1.56 & 2.74 & 0.64 & II \\
\hline \multicolumn{4}{|c|}{ M-Sand (Average) } & 1.49 & 2.84 & 0.82 & \multirow{4}{*}{ III } \\
\hline 1 & R-sand & $\mathrm{Fe} 415$ & Steel & 1.29 & 1.97 & 0.95 & \\
\hline 2 & R-sand & $\mathrm{Fe} 415$ & $\mathrm{PF}$ & 1.27 & 1.92 & 0.97 & \\
\hline 3 & R-sand & $\mathrm{Fe} 415$ & Nil & 1.35 & 1.91 & 0.91 & \\
\hline \multicolumn{4}{|c|}{ R-Sand (Average) } & 1.30 & 1.93 & 0.94 & \\
\hline
\end{tabular}




\section{9) CONCLUSIONS}

Following conclusions are drawn based on room temperature cured fly ash- slag based reinforced geopolymer concrete flexural elements.

- The flexural behaviour of Reinforced Geopolymer Concrete is similar to Conventional OPC based RCC elements. IS: 456-2000 of Indian RC Design Code can be used to estimate all structural design related output.

- Using M-sand ductility of GPC could be in the range 1.50 to 2.85 and Using River sand it could be in the range 1.30 to 1.95 . The average of these two ductilities of RGPC lies between $\mathbf{1 . 4}$ and $\mathbf{2 . 4 0}$.

- If fine aggregates and coarse aggregates are of the same rock origin, then the ductility of GPC is more with appreciable bond strength.

- Using proper steel grade \& fibres at 10 to $15 \%$ could increase the strength and ductility of GPC.

\section{REFERENCES}

[1] Prakash Desai, K. U. Muthu, A brief review on strength, deflection and cracking of rectangular, skew and circular reinforced concrete slabs, Indian Institute of Science, 91-108,(Mar-Apr. 1988).

[2] Djwantoro Hardjito, Studies on Fly Ash-based Geopolymer Concrete, Thesis Report, Curtain University of Technology, (Nov.2005).

[3] Radhakrishna et al., Strength Characteristics of Open Air Cured Geopolymer Concrete, Transactions of the Indian Ceramic Society, (Feb.2014).

[4] Rajamane et al., Quantities of Sodium hydroxide solids and water to prepare sodium hydroxide solution of given molarity for geopolymer concrete mixes, ICI technical paper, (Sept. 2014).

[5] N. Ganesan et al., Development of stress block parameters for geopolymer concrete, The Indian Concrete Journal, vol 89, Issue 9, pp 47-56, (Sept. 2015).

[6] Mahantesh et al., Flexural behaviour of fly ash-slag based reinforced geopolymer concrete flexural elements cured at room temperature, IJTAM, ISSN 0973-6085, Volume 12, Number 4, PP 845-856, (2017).

[7] Mahantesh et al. , Strength and Deformation Behavior of Reinforced Geopolymer Concrete Flexural Elements, IJCIET, ISSN 0976-6316, Volume 8, Issue 5, PP 1108 1121, (May 2017).

[8] Robert Park \& Thomas Paulay, Reinforced Concrete Structures, John Wiley \& Sons, INC.UK, (2013).

[9] IS 456-2000, Indian standard code of practice for plain and reinforced concrete for general building construction, Bureau of Indian Standards - New Delhi, (2000)

[10] Sumajouw and Rangan, Low Calcium Fly Ash-based Geopolymer Concrete: Reinforced Beams and Columns, Research Report GC3, Curtin University of Technology, (2006). 


\section{ACKNOWLEDGEMENTS}

- The Authors wish to express their grateful feelings and thank the management of Alliance University and The Oxford College of Engineering - Bangalore, for their kind support while investigating this research work during 2013 - 2016.

- The Authors also wish to thank EACEF 2017 for their excellent support during the conference at Seoul- South Korea. 